\title{
Keabsahan Direktur Perusahaan Pailit yang Menjadi Direktur Perusahaan Lain
}

\author{
Iman Rahmat Feisal \\ Universitas Airlanga \\ imanrf1304@gmail.com
}

\begin{abstract}
This research is based on uncertainty due to bankruptcy, especially regarding the rights of bankrupt company directors who cannot become directors of other companies within 5 (five) years after being declared bankrupt. The purpose of this study is to examine why directors of bankrupt companies cannot become directors of other companies and examine the legal remedies for directors of bankrupt companies to become directors of other companies. This research is a normative study, with a statutory approach, a conceptual approach, and a case approach. The results showed that the conditions for limiting a director to a bankrupt company to become a director in another company were contrary to the provisions concerning the effects of bankruptcy which stated that a bankrupt person simply does not have power over his assets. Legal remedies that can be carried out by directors who have been declared bankrupt to become directors in other companies are by carrying out tort actions against the Notary and the Ministry of Law and Human Rights. The Ministry of Law and Human Rights can also be sued in the State Administrative Court because it is not in accordance with the General Principles of Good Governance.
\end{abstract}

\section{Keywords: Rights, Directors, Limited Liability Companies, Bankruptcy.}

\begin{abstract}
Abstrak
Penelitian ini bermula dari ketidakjelasan akibat dari kepailitan terutama mengenai hak direktur perusahaan pailit yang tidak dapat menjadi direktur di perusahaan lain dalam jangka waktu 5 (lima) tahun setelah dinyatakan pailit. Tujuan penelitian ini adalah untuk mengkaji mengapa direktur pada perusahaan pailit tidak dapat menjadi direktur di perusahaan lain serta mengkaji upaya hukum bagi direktur pada perusahaan pailit untuk dapat menjadi direktur di perusahaan lain. Penelitian ini merupakan penelitian yuridis normatif, dengan pendekatan peraturan perundang-undangan (statute approach), pendekatan konseptual (conceptual approach), dan pendekatan kasus (case approach). Hasil penelitian menunjukkan bahwa syarat pembatasan seorang direksi yang pailit untuk menjadi direksi diperusahaan lain terjadi konflik dengan pengaturan akibat kepailitan yang menyatakan seorang yang pailit hanya tidak berkuasa terhadap harta kekayaannya saja. Hal tersebut bertentangan dengan konsep dasar hak keperdataan. Upaya hukum yang dapat dilakukan direksi yang pernah dinyatakan pailit untuk menjadi direksi diperusahaan lain adalah dengan melakukan gugatan perbuatan melawan hukum kepada Notaris dan Kementerian Hukum dan Hak Asasi Manusia. Kementerian Hukum dan Hak Asasi Manusia dapat digugat juga di Peradilan Tata
\end{abstract}


Usaha Negara karena tidak sesuai dengan Asas-Asas Umum Pemerintahan yang Baik.

\section{Kata Kunci : Hak, Direksi, Perseroan Terbatas, Kepailitan.}

\section{Pendahuluan}

Pailit merupakan suatu keadaan dimana debitur tidak mampu untuk melakukan pembayaran terhadap utang-utang dari para krediturnya. Dalam Black's Law Dictionary, pengertian pailit dihubungkan dengan "kemampuan untuk membayar" dari seseorang (debitur) atas utang-utangnya yang telah jatuh tempo (Yani, 2004 : 11). Adanya peraturan perundang-undangan tentang kepailitan adalah untuk menjamin dan melindungi hak-hak para kreditor. Kepailitan merupakan keadaan setelah putusan pengadilan niaga yang mengakibatkan sitaan umum "terhadap seluruh kekayaan Debitor pailit, baik yang telah ada pada saat putusan pailit maupun yang akan ada atau diperoleh" selama kepailitan (Subhan, 2012 : 1). Undang-Undang Nomor 37 Tahun 2004 tentang Kepailitan dan Penundaan Kewajiban Pembayaran Utang tidak membedakan secara spesifik antara kepailitan perorangan dan badan hukum, namun terdapat norma yang hanya bisa diberlakukan pada kepailitan perorangan tetapi tidak dapat diberlakukan pada kepailitan badan hukum. Sebaliknya, juga terdapat norma yang hanya dapat diberlakukan pada kepailitan badan hukum tetapi tidak dapat diberlakukan pada kepailitan perorangan. Pengaturan yang khusus mengatur kepailitan perorangan dan khusus mengatur kepailitan badan hukum belum ada pada UndangUndang Nomor 37 Tahun 2004 tentang Kepailitan dan Penundaan Kewajiban Pembayaran (selanjutnya disebut Undang Undang Kepailitan) (Subhan, 2012 : 1).

Pernyataan pailit mengakibatkan debitur demi hukum kehilangan hak untuk menguasai dan mengurus kekayaannya yang dimasukan dalam kepailitan bukan untuk membatasi hak secara pribadi ataupun individu. Dengan ditiadakannya hak debitur secara hukum untuk mengurus kekayaannya, maka oleh Undang Undang Kepailitan sejak tanggal 
putusan pernyataan pailit ditetapkan, yang berhak membagi harta debitur pailit dan melaksanakan tugas pengurusan dan pemberesan terhadap harta debiturtersebut adalah kurator.

Menurut Pasal 1 ayat (1) Undang Undang Kepailitan yang berlaku saat ini dapat disimpulkan bahwa kepailitan bertujuan untuk menghindari penyitaan dan eksekusi yang dilakukan oleh seorang kreditor secara pribadi melalui Pengadilan Niaga (Hartono, 2012 : 26). Pihak yang dapat diangkat menjadi anggota direksi adalah orang perseorangan yang cakap melakukan perbuatan hukum. Pada Pasal 93 Ayat (1) Undang-Undang Nomor 40 Tahun 2007 Tentang Perseroan Terbatas mengatakan bahwa syarat untuk menjadi seorang direksi pada sebuah perusahaan tidak pernah dinyatakan pailit selama 5 tahun terakhir.

Hal ini mengakibatkan kedua peraturan perundang - undangan ini bergesekan dan ketidakjelasan dengan adanya akibat pernyataan pailit dan syarat menjadi direksi yang nantinya akan menimbulkan konflik hukum yaitu apakah direksi akibat pailit hanya menyebabkan seseorang kehilangan hak untuk menguasai harta kekayaannya atau kehilangan hak pribadinya untuk bekerja sebagai direksi juga. Bahwa akibat dari penyataan pailit tidak membatasi hak pribadi individu, sedangkan syarat menjadi direksi menurut Undang Undang Perseroan Terbatas salah satunya tidak pernah dinyatakan pailit, hal tersebut membatasi hak pribadi individu untuk bekerja dengan adanya pernyataan pailit. Adanya batasan seorang yang dinyatakan pailit tidak dapat menjadi direksi dan komisaris pada suatu perusahaan berbentuk Perseroan Terbatas mengakibatkan ketidakjelasan.

Di Indonesia terdapat maskapai Indonesian Airlines yang didirikan pada tahun 1999 oleh Rudy Setyopurnomo mulai beroperasi tahun 2001. Tidak lama kemudian Indonesian Airlines mengalami pailit, yang menurut keterangan Rudy sendiri sebagai pendiri maskapai tersebut tutup dikarenakan para pemegang saham sudah tidak ingin melanjutkan bisnis dibidang penerbangan (Dhany, 2012 : $\underline{\text { www.finance.detik.com, dikunjungi }}$ 
pada tanggal 12 November 2015), sehingga menurut Pasal 93 Undang Undang Perseroan Terbatas Rudy tidak memenuhi syarat menjadi direksi kembali selama 5 (lima tahun) terakhir. Pada tahun 2012 Rudy Setyopurnomo diangkat oleh Dahlan Iskan sebagai direksi Merpati Airlines.

Permasalahan tersebut yang melatar belakangi penelitian ini. Latar belakang ini memfokuskan konflik hukum yang terjadi antara syarat menjadi direksi yang mengharuskan tidak pernah dinyatakan pailit yang ada dalam Pasal 93 Undang-Undang Nomor 40 Tahun 2007 Tentang Perseroan Terbatas dengan akibat kepailitan yang hanya membatasi debitor untuk mengurus dan menguasai harta kekayaannya terdapat didalam Pasal 24 Ayat (1) Undang-Undang Kepailitan. Adapun rumusan masalahnya adalah mengapa direktur pada perusahaan pailit tidak dapat menjadi direktur di perusahaan lain , dan apa upaya hukum bagi direktur pada perusahaan pailit untuk dapat menjadi direktur di perusahaan lain.

\section{Metode Penelitian}

Tipe penelitian dalam penelitian ini adalah menggunakan penelitian hukum (legal research) dengan cara meneliti bahan hukum yang diperoleh dari peraturan perundangundangan dan bahan-bahan kepustakaan di bidang hukum yang berkaitan dengan masalah Kemudian bahan hukum yang diperoleh tersebut selanjutnya disusun secara sistematis dengan menggunakan studi yuridis normatif.

Penulisan ini menggunakan metode penelitian yuridis normatif. Metode penelitian yuridis normatif yaitu pendekatan perundang undangan melalui studi kepustakaan dengan berpijak pada peraturan perundang - undangan yang berlaku saat ini.

Penelitian ini menggunakan pendekatan masalah secara pendekatan peraturan perundangundangan (statute approach), pendekatan konseptual (conceptual approach), dan pendekatan kasus (case approach). Pendekatan peraturan perundang-undangan (statute approach), yaitu pendekatan yang dilakukan dengan menelaah 
semua undang-undang dan regulasi yang bersangkut-paut dengan isu hukum yang sedang ditangani (Marzuki, 2005 : 93). Pendekatan konseptual (conceptual approach), yaitu pendekatan yang dilakukan dengan mempelajari pandanganpandangan dan doktrin-doktrin dalam ilmu hukum (Marzuki, 2005 : 95). Pendekatan kasus (case approach) yaitu meneliti alasan alasan hukum yang digunakan hakim untuk sampai pada putusannya.

\section{Hasil dan Pembahasan}

Direktur Yang Terkena Pailit Tidak Dapat Menjadi Direktur Di Perusahaan Lain

Perseroan Terbatas (selanjutnya disebut PT) berkaitan erat dengan pertanggungjawaban suatu kegiatan yang telah dilakukan oleh badan hukum tersebut. Dalam situasi ekonomi yang tidak menentu pada saat ini PT merupakan pilihan untuk menjalankan aktivitas bisnis dan tidak menutup kemungkinan suatu PT mengalami kesulitan di bidang keuangan. PT mengalami kesulitan dalam bidang keuangannya maka akan berdampak kewajiban untuk membayar utangnya kepada para kreditornya. Ketika PT tidak sanggup membayar utang ke kreditor dan utang tersebut telah jatuh tempo maka kreditor dapat melakukan upaya hukum yaitu gugatan pailit ke Pengadilan Niaga yang nantinya mengeluarkan putusan pernyataan pailit yang ditujukan ke debitor.

Menurut hukumnya, PT melakukan suatu perbuatan hukum untuk dan atas namanya sendiri sebagai subjek hukum bukan oleh orang-orang yang melakukan perbuatan tersebut. Sebagai konsekuensinya segala akibat dan hutang yang timbul tersebut harus ditanggung oleh PT itu sendiri dengan segala harta kekayaan PT yang bersangkutan, tanpa sedikitpun meminta pertanggungjawaban dan atau menuntut untuk dibayar dari kekayaan pribadi orang yang melakukan perbuatan, sekalipun yang melakukan perbuatan tersebut adalah pemegang saham PT (Prasetya, 2001 : 50). Suatu PT dipandang sebagai subjek hukum yang mandiri karenanya suatu tagihan kepada PT tidak dapat 
dibebankan atau ditagihkan kepada harta kekayaan pribadi pegurusnya.

Tanggung Jawab PT yang dinyatakan pailit oleh Putusan Pengadilan Niaga maka PT tersebut harus melakukan keterbukaan terhadap kreditornya atas segala kegiatan yang nantinya akan berpengaruh atas harta kekayaan PT. Sebuah PT tidak diperbolehkan melakukan kegiatan transaksi terkecuali dalam hal likuidasi atau pemberesan yaitu menagih utangutang, menjual aset PT yang nantinya akan digunakan untuk membayar seluruh utang kepada kreditur.

PT dituntut untuk bertanggungjawab kepada para kreditor yang telah memberikan pinjaman kepada PT. Dalam memberikan pinjaman kreditor biasanya melihat terlebih dahulu kemampuan dari PT dalam menjalankan usahanya Perseroan Terbatas harus bertanggungjawab dalam memenuhi kepentingan utama kreditor untuk mendapatkan keuntungan maksimal dan menekan seminimal mungkin terjadinya kerugian sehingga risiko untuk mengalami kegagalan dalam mengembalikan pinjaman tidak terjadi. Untuk itu Perseroan Terbatas harus menjaga modal dan seluruh harta kekayaan Perseroan Terbatas. Perlindungan modal dan harta kekayaan dalam rangka pembelian kembali saham yang telah dikeluarkan juga merupakan bentuk dari tanggung jawab PT.

Dalam hal kepailitan PT dituntut untuk memenuhi kepentingan kreditur untuk dapat membayar seluruh kewajibannya. Pengaturan mengenai tanggung jawab perseroan terbatas diatur dalam pasal 104 ayat 2 dan pasal 115 ayat 1 UndangUndang Perseroan Terbatas.

Pasal 104 ayat 2 UndangUndang Perseroan Terbatas :

Dalam hal kepailitan terjadi karena kesalahan atau kelalaian direksi dan harta pailit tidak cukup untuk membayar seluruh kewajiban Perseroan dalam kepailitan tersebut, setiap anggota direksi secara tanggung renteng bertanggung jawab atas seluruh kewajiban yang tidak terlunasi dari harta pailit tersebut.

Pasal 115 ayat 1 UndangUndang Perseroan Terbatas : 
Dalam hal terjadi kepailitan karena kesalahan atau kelalaian dewan komisaris dalam melakukan pengawasan terhadap pengurusan yang dilaksanakan oleh direksi dan kekayaan Perseroan tidak cukup untuk membayar seluruh kewajiban Perseroan akibat kepailitan tersebut, setiap anggota dewan komisaris secra tanggung renteng ikut bertanggung jawab dengan anggota direksi atas kewajiban yang belum terlunasi.

Dari kedua pasal tersebut terdapat klausul "harta pailit tidak cukup untuk membayar seluruh kewajiban Perseroan dalam kepailian" dalam pasal 104 Ayat (2) dan "Kekayaan Perseroan tidak cukup membayar seluruh kewajiban Perseroan akibat kepailitan" dalam pasal 115 Ayat (1), maka dapat disimpulkan bahwa yang nantinya jika Perseroan Terbatas mengalami kepailitan adalah harta kekayaan Perseroan Terbatas itu sendiri.

Dalam Perseroan Terbatas pengurus hanya sebagai organ, maka tidak bertanggung jawab atas perbuatannya melainkan menjadi tanggung jawab Perseroan Terbatas yang diwakilinya (Prasetya, 2001 : 207).

Dari ketentuan normatif Pengurusan berkaitan dengan melakukan tugas-tugas internal untuk mencapai maksud dan tujuan dari Perseroan Terbatas yang bersangkutan, sedangkan Perwakilan berkaitan sebagai penghubung dengan pihak ketiga dan mewakili Perseroan Terbatas baik didalam maupun di luar Pengadilan (Subhan, 2012 : 226).

Mengenai tanggung jawab direksi, Undang-Undang Perseroan Terbatas menganut prinsip presumsi bersalah (premption of guilt) bagi semua anggota direksi. Dengan artian, hukum menganggap semua anggota direksi bertanggung jawab renteng yaitu secara sendiri-sendiri dan/atau bersama-sama atas seluruh kerugian pihak lain, tanggung jawab mana berlaku atas segala perbuatan oleh direksi untuk dan atas nama perseroan. Jadi, dalam hal ini direksi dilihat secara keseluruhan dalam satu kesatuan meskipun dalam kenyataannya tindakan tersebut hanya dilakukan oleh seorang Direksi saja (Fuady, 2003 : 78). 
Ketentuan Pasal 90 Ayat (2) dan Ayat (3) UUPT disesuaikan sebagaimana yang dimaksud dalam Pasal 85 Ayat (1) UUPT bahwa tugas, wewenang, dan tanggung jawab pengurusan PT untuk kepentingan dan usaha PT dipercayakan dan dibebankan kepada setiap anggota direksi tanpa pengecualian, baik kelalaian maupun kesalahan seorang atau lebih anggota direksi berakibat bahwa seluruh direksi yaitu masing-masing anggota direksi harus menanggung akibat tersebut, tanggung jawab kolegial inilah yang dimaksud dalam Pasal 90 Ayat (2) UUPT. Yang harus membuktikan bahwa kepailitan suatu PT terjadi karena adanya kesalahan atau kelalain dari direksi adalah pihak yang mendalilkannya. Apabila berhasil dibuktikan oleh pihak yang mendalilkan tersebut maka sesuai dengan ketentuan Pasal 90 Ayat (2) UUPT setiap anggota direksi karena hukum secara tanggung renteng bertanggung jawab atas kerugian akibat kepailitan PT yang tidak dapat dilunasi dengan harta kekayaan PT, kecuali anggota direksi dapat membuktikan bahwa dirinya tidak melakukan kesalahan ataupun kelalaian yang mengakibatkan pailitnya suatu PT. Sesuai ketentuan yang dimaksud dalam Pasal 90 Ayat (3) UUPT beban pembuktian ada pada anggota direksi (Subhan, 2012 : 234).

Dalam hal suatu Perseroan Terbatas mengalami kepailitan yang disebabkan oleh kesalahan atau kelalaian anggota direksi, maka saat harta kekayaan Perseroan Terbatas tidak dapat melunasi seluruh piutang pailit secara tanggung renteng anggota direksi wajib bertanggung jawab atas seluruh kewajiban yang tidak terlunasi, hal ini dijelaskan dalam Pasal 104 Ayat (2) UndangUndang Perseroan Terbatas. Setiap anggota Direksi secara tanggung renteng bertanggung jawab atas seluruh kewajiban yang tidak terlunasi dari harta pailit tersebut. Tanggung jawab tersebut, berdasarkan pasal 104 Ayat (3), berlaku juga bagi anggota Direksi yang salah atau lalai yang pernah menjabat sebagai anggota Direksi dalam jangka waktu 5 (lima) tahun sebelum putusan pernyataan pailit diucapkan. 
Jika dilihat dari ketentuanketentuan di atas maka direksi yang telah dinyatakan pailit tidak dapat mengakibatkan tidak cakap hukum ataupun dibawah pengampuan, hanya saja direksi tidak cakap untuk menguasai dan mengurus harta kekayaannya saja. Ketentuan dalam Undang-Undang Kepailitan juga mengatakan bahwa seseorang yang dinyatakan pailit tidak cakap lagi untuk mengurus harta kekayaannya tetapi kewenangan untuk menjadi seorang pribadi sebagai subjek hukum masih ada.

Terpenuhinya syarat formal yaitu tidak pernah dinyatakan pailit yang ditentukan Pasal 93 Ayat (1) Undang-Undang Nomor 40 Tahun 2007 tentang Perseroan Terbatas mengakibatkan sempurnanya tindakan Direksi sebagai wakil dari Perseroan Terbatas, dan dengan demikian berarti semua tindakan yang dilakukan oleh Direksi adalah merupakan tanggung jawab dari perseroan dan bukan tanggung jawab pribadi yang melakukan perbuatan hukum tersebut. Tetapi dengan terpenuhinya syarat formalitas tersebut bukan berarti Direksi dapat melaksanakan fungsi, tugas, dan wewenangnya secara baik untuk tercapainya tujuan Perseroan Terbatas (Yanda, $2005:$ 11).

\section{Upaya Hukum Bagi Direktur Yang} Terkena Pailit Untuk Dapat Menjadi Direktur Di Perusahaan Lain

Undang-Undang Perseroan Terbatas No.40 Tahun 2007 menentukan syarat-syarat seseorang yang dapat diangkat menjadi direksi, yaitu orang perseorangan yang cakap melakukan perbuatan hukum, kecuali dalam waktu 5 (lima) tahun sebelum pengangkatannya pernah (Widyono, $2008: 73)$ :

a) Dinyatakan pailit;

b) Menjadi anggota direksi atau anggota dewan komisaris yang dinyatakan bersalah menyebabkan suatu perseroan dinyatakan pailit;

c) Dihukum karena melakukan tindak pidana yang merugikan keuangan Negara dan/ atau yang berkaitan dengan sektor keuangan.

Pengangkatan direksi yang tidak memenuhi syarat-syarat tersebut menjadi batal karena hukum. Hal ini ditegaskan dalam Pasal 95 Ayat (1) UU Perseroan Terbatas, bahwa pengangkatan direksi yang tidak 
memenuhi persyaratan sebagaimana dimaksud dalam Pasal 93 batal karena hukum sejak saat anggota direksi lainnya atau dewan komisaris mengetahui tidak terpenuhinya persyaratan tersebut (Widyono, 2008 :74).

Tindakan hukum yang harus dilakukan oleh direksi atau dewan komisaris (Widyono, 2008 : 74):

1) Memberitahukan secara tertulis kepada anggota direksi yang bersangkutan Direksi dan dewan komisaris yang mengetahui tidak terpenuhinya syarat dalam suatu pengangkatan seorang anggota direksi haruslah :

a) Memberitahukan hal itu kepada anggota direksi yang bersangkutan,

b) Pemberitahuan disampaikan dalam bentuk tertulis,

c) Pemberitahuan dilakukan pada saat di ketahui hal tersebut.

2) Mengumumkan batalnya pengangkatan dalam surat kabar. Batalnya pengangkatan seorang anggota direksi, anggota direksi lain atau dewan komisaris harus :

a) Mengumumkannya dalam surat kabar

b) Jangka waktu pengumuman paling lambat 7 (tujuh) hari, terhitung sejak diketahui tidak terpenuhinya syarat pengangkatan oleh anggota direksi lainnya atau dewan komisaris.

3) Memberitahukan pembatalan pengangkatan kepada menteri.
Tindakan selanjutnya yang harus dilakukan oleh anggota direksi dan dewan komisaris menyangkut pembatalan pengangkatan, sesuai dengan Pasal 95 ayat (2) adalah :

a) Memberitahukan pembatalan pengangkatan tersebut kepada menteri,

b) Pemberitahuan tersebut agar pembatalan tersebut kemudian dicatat oleh menteri dalam daftar perseroan sesuai dengan Pasal 29 ayat (3) huruf c dalam kategori perubahan data perseroan berdasar penjelasan Pasal 29 ayat (3) huruf c. Anggota direksi dapat diberhentikan sewaktuwaktu berdasarkan keputusan RUPS dengan menyebutkan alasannya. Keputusan RUPS untuk memberhentikan anggota direksi dapat dilakukan dengan alasan yang bersangkutan tidak lagi memenuhi persyaratan sebagai anggota direksi yang ditetapkan dalam UUPT. Dalam hal keputusan untuk memberhentikan direksi dilakukan dengan keputusan diluar RUPS, sesuai dengan ketentuan sebagaimana dimaksud dalam Pasal 91 UUPT, anggota direksi yang brsangkutan diberi tahu terlebih dahulu tentang rencana pemberhentian dan diberikan kesempatan untuk membela diri sebelum diambil keputusan pemberhentian (Widyono, $2008: 76$ ) 
Perbuatan melawan hukum dalam sistem hukum di Indonesia diatur dalam Pasal 1365 sampai denga Pasal 1380 KUH Perdata. Pada Pasal 1365 KUH Perdata dijelaskan secara khusus mengenai definisi dari perbuatan melawan hukum yang mengatakan :

"Setiap perbuatan onrechtmatig yang mengakibatkan kerugian kepada orang lain mewajibkan orang karena salahnya menerbitkan itu mengganti kerugian tersebut".

Dari definisi tersebut maka kita dapat menetukan yang menjadi unsur-unsur perbuatan melawan hukum menurut Pasal 1365 KUH Perdata (Sriwiyati, 2003 : 26):

a) Perbuatan yang menimbulkan kerugian itu bersifat melanggar hukum.

b) Kerugian itu timbul sebagai akibat perbuatan tersebut.

c) Pelaku tersebut bermasalah .

d) Norma yang dilanggar mempunyai "strekking" untuk mengelakkan timbulnya kerugian.

$\begin{array}{ccr}\text { Peran } & \text { Notaris } & \text { dalam } \\ \text { hubungannya } & \text { dengan } & \text { Perseroan }\end{array}$

Terbatas (PT) yaitu:

1) Akta pendirian PT;
2) akta Perubahan status badan hukum

3) akta pengalihan Saham

Kode etik notaris merupakan sebuah kaidah moral yang ditentukan oleh perkumpulan Ikatan Notaris Indonesia berdasarkan Keputusan Kongres Perkumpulan yang ditentukan dan diatur dalam peraturan perundang-undangan yang mengatur tentang hal itu dan yang berlaku,bagi, serta wajib ditaati oleh setiap anggota perkumpulan dan smeua orang yang menjalankan tugas dan jabatan Notaris (Anshori, 2010 : 162).

Kesalahan Notaris akibat perbuatannya atau pun dalam membuat akta menyebabkan timbulnya kerugian kepada pihak lain dapat dikategorikan sebagai perbuatan melawan hukum karena kelalaian. Akibat adanya perbuatan hukum yang dilakukan oleh notaris dalam menjalankan tugasnya menimbulkan adanya pertanggungjawaban yang harus dilakukan oleh notaris.

Peran notaris hanya mencatat atau menuangkan suatu perbuatan hukum yang dilakukan oleh pihak 
yang menghadapnya. Notaris tidak diwajibkan untuk menyelidiki kebenaran isi materiil dari akta otentik tersebut. Notaris harus bersikap netral dalam membuatkan akta otentik. Jika kesalahan yang dilakukan oleh notaris dapat dibuktikan, maka notaris dapat dikenakan sanksi sebagaimana yang telah ditentukan oleh undangundang.

Dalam rangka melaksanakan tugasnya, Pemerintah melakukan tindakan-tindakan yang tentu akan menyangkut kepentingan orang. Yang mana setiap tindakan yang dilakukan Pemerintah itu disatu pihak akan membawa keuntungan, tetapi di lain pihak tidak jarang akan merugikan orang-orang tertentu. Dengan demikian, tidak dapat dipungkiri bahwa dalam rangka memenuhi kebutuhan untuk kepentingan umum, kadang-kadang Pemerintah merugikan orang Perseorangan. Dalam hal yang demikian, Pemerintah sebagai Penguasa seyogyanya dalam melakukan tindakan selalu harus mempertimbangkan kepentingan yang perlu dilindungi.
Perbuatan melawan hukum tidak hanya berarti berbuat (atau tidak berbuat) yang melanggar hak subyektif orang lain ataupun bertentangan dengan kewajiban hukum si pelaku, akan tetapi meliputi juga berbuat atau tidak berbuat yang bertentangan dengan azas kepatutan, ketelitian serta sikap kehati-hatian yang seharusnya dimiliki seseorang dalam pergaulannya dalam masyarakat terhadap milik orang lain. Penguasa dapat juga melakukan tindakan yang melawan/melanggar azas kepatutan tadi, apabila Penguasa ikut ambil bagian dalam suatu kegiatan dalam kedudukannya yang sama dengan orang perseorangan, dengan cara melakukan perbuatanperbuatan yang menurut hakikatnya tidak hanya dapat dilakukan oleh Penguasa, akan tetapi dapat juga dilakukan oleh orang perseorangan.

Kementerian Hukum dan HAM dalam hal ini telah diduga terkait penerbitan Undang-Undang Nomor 40 Tahun 2007 tentang Perseroan Terbatas dimana dalam undangundang tersebut terdapat pasal yang membatasi hak seorang direksi yang pernah dinyatakan pailit untuk tidak 
dapat menjadi direksi di perusahaan lain. Secara tidak langsung peraturan tersebut telah melanggar hak subyektif seseorang untuk bekerja dan mencari nafkah yang secara alamiah merupakan kegiatan untuk memenuhi kehidupannya. Akibat pailit hanyalah sebatas ketidak berwenangan seseorang untuk menguasai harta kekayaannya saja bukan membatasi seseorang untuk bekerja dimana itu adalah hak pribadi sebagai subyek hukum.

Dengan melakukan sesuatu yaitu telah menerbitkan suatu undangundang yang merupakan tindakan hukum dan undang-undang tersebut dapat merugikan hak subyektif seseorang maka kementrian hukum dan HAM telah melakukan perbuatan melawan hukum. Direksi yang sebelumnya pernah pailit secara hukum tidak dapat menjadi direksi di perusahaan lain akibat terbitnya undang-undang tersebut. Upaya hukum yang dapat dilakukan adalah mengajukan gugatan perbuatan melawan hukum ke peradilan umum terhadap Kementerian Hukum dan HAM akibat undang-undang yang diterbitkan. Pada hakikatnya
Kementerian Hukum dan HAM harus menjaga dan melindungi segala hak asasi manusia setiap masyarakat Indonesia dan perlu kehati-hatian dalam menyetujui penerbitan undang-undang sehingga tidak menyebabkan kerugian subyektif pada seseorang tertentu.

Fungsi hukum ialah menegakkan kebenaran untuk mencapai keadilan. Keadilan adalah merupakan hal yang pokok bagi manusia dalam hidup bermasyarakat, maka dibutuhkan adanya lembaga-lembaga yang bertugas menyelenggarakan keadilan ini. Keadilan ini dituntutkan untuk semua hubungan masyarakat, hubungan-hubungan yang diadakan oleh manusia dengan menusia lainnya, oleh karena itu berbicara tentang keadilan meliputi segala kehidupan manusia dalam hubungannya dengan manusia lain. Keadilan ini erat hubungannya dengan kebenaran, karena sesuatu yang tidak benar tidaklah mungkin adil. Sesuatu itu benar menurut norma-norma yang berlaku akan tercapailah keadilan itu.

Ciri khas hukum acara peradilan tata usaha negara terletak pada asas- 
asas yang melandasinya, yaitu (Hadjon, 2008 : 313):

1) Asas praduga rechmatig Asas ini mengandung makna bahwa setiap tindakan penguasa selalu harus dianggap rechmatig sampai adanya pembatalan. Dengan asas ini, gugatan tidak menunda pelaksanaan KTUN yang digugat seperti yang diterangkan dalam Pasal 67 Ayat (1) UU Nomor 5 Tahun 1986.

2) Asas pembuktian bebas

Hakim yang menetapkan beban pembuktian. Hal ini berbeda dnegna ketentuan pasal 1865 KUH Perdata. Asas ini dianut oleh Pasal 107 UU Nomor 5 Tahun 1986.

3) Asas keaktifan hakim

Keaktifan hakim dimaksudkan untuk mengimbangi kedudukan para pihak karena tergugat adalah pejabat tata usaha negara, sedangkan penggugat adalah orang atau badan hukum perdata.

4) Asas putusan pengadilan mempunyai kekuatan mengikat Sengketa TUN adalah sengketa hukum publik. Dengan demikian, putusan pengadilan TUN berlaku bagi siapa saja, tidak hanya bagi para pihak yang bersengketa.

Bagi KTUN yang tidak mengenal adanya upaya administratif, gugatan ditujukan kepada PTUN sedangkan bagi KTUN yang mengenal adanya upaya administratif gugatan langsung ditujukan kepada pengadilan tinggi tata usaha negara. Menurut UU Nomor 5 Tahun 1986, setiap KTUN yang berasal dari kepala daerah yang menjadi sengketa tata usaha negara harus melalui upaya administratif dan selanjutnya akan digugat melalui pengadilan tinggi tata usaha negara (Hadjon, 2008 : 317).

Pada Pasal 1 Angka 4 UU Nomor 5 Tahun 1986 merumuskan sengketa yang timbul dalam bidang tata usaha negara, baik di pusat maupun di daerah sebagai akibat dikeluarkannya keputusan tata usaha negara termasuk sengketa kepegawaian berdasarkan peraturan perundang-undangan yang berlaku. Dengan demikian, KTUN merupakan dasar lahirnya sengketa tata usaha negara (Hadjon, 2008 : 318).

Berdasarkan ketentuan Pasal 53 Ayat (1) UU Nomor 5 Tahun 1986 yang 
dapat bertindak sebagai penggugat adalah :

1) Orang atau badan hukum perdata

2) Yang kepentingannya dirugikan oleh suatu KTUN

Ketetapan merupakan wujud konkret dari tindakan hukum pemerintahan. Secara teoritis, tindakan hukum berarti tindakantindakan yang berdasarkan sifatnya dapat menimbulkan akibat hukum tertentu atau tindakan hukum adalah tindakan yang dimaksudkan untuk menciptakan hak dan kewajiban (Ridwan, 2007 : 160).

Sikap mengabaikan atau mendiamkan permohonan jelas dapat menimbulkan kerugian di pihak warga masyarakat yang memohonkannya. Di dalam teori tentang etika administrasi negara, salah satu cara untuk mengawasi dan mencegah terjadinya sikap mengabaikan dalam memberikan pelayanan kepada masyarakat adalah dengan melakukan apa yang disebut sebagai sistem pertanggungjawaban legal. Hukum administrasi mengatur bahwa sikap diam pejabat TUN dalam menerbitkan sebuah KTUN biasa dikenal dengan Keputusan Fiktif Negatif (Basah, 1989 : 3-4).

Kedudukan pemerintah yang serba khusus terutama karena sifatsifat istimewa yang melekat padanya, yang tidak dimiliki oleh manusia biasa, telah menyebabkan perbedaan pendapat dengan apakah negara dapat digugat atau tidak diepan hakim. Pemerintah dalam menjalankan tugasnya memerlukan kebebasan bertindak dan mempunyai kedudukan istimewa dibandingkan dengan rakyat biasa (Ridwan, 2007 : 284).

Kementerian Hukum dan HAM telah melakukan tindakan hukum dengan menerbitkan UU Nomor 40 Tahun 2007 tanpa memperhatikan hak direksi sebagai individu. Direksi dapat melakukan gugatan terhadap Kementerian Hukum dan HAM dengan dasar AUPB yang tidak sesuai dan menimbulkan akibat hukum yang membatasi hak individu serta telah melakukan KTU fiktif negatif dengan timbulnya direksi yang pernah dinyatakan pailit untuk tidak dapat menjadi direksi di perusahaan lain dalam kurun waktu 5 
(lima) tahun setelah dinyatakan pailit.

PT Indonesian Airlines Aviapatria didirikan tahun 1999 dan mulai beroperasi Maret 2001. Pada September 1999, ia memperoleh izin dari pemerintah Indonesia untuk melakukan penerbangan berjadwal di 46 rute. Perusahaan ini dimiliki oleh investor perorangan (75\%) dan Rudy Setyopurnomo (25\%), Presiden Direktur maskapai ini. Indonesian Airlines menghentikan operasinya pada tahun 2003. Setelah itu kantor pusatnya juga ditutup.Rudy Setyopurnomo kemudian bekerja pada Grup RGM Group yang mengoperasikan 4 pesawat kecil sebelum akhirnya dipilih Menteri BUMN Dahlan Iskan untuk memimpin maskapai pelat merah, PT Merpati Nusantara Airlines (MNA) Maskapai ini pernah mengoperasikan 1 Boeing 727-200, 2 Boeing 737-300 dan 2 Boeing 747 (Aditya, www.finance.detik.com dikunjungi pada tanggal 12 November 2015).

a) Analisa Kasus

Rudy Setyopurnomo yang pernah dinyatakan pailit pada tahun
2003 pada saat menjabat menjadi direktur PT. Indonesian Airlines Aviapatria terbukti dapat diangkat menjadi direktur kembali di PT. Merpati Nusantara Airlines oleh Menteri BUMN Dahlan Iskan pada tahun 2012. Maka sesuai Pasal 93 UU Nomor 40 Tahun 2007 tentang Perseroan Terbatas, seseorang baru dapat diangkat kembali menjadi direksi dengan syarat lima tahun terakhir tidak pernah dinyatakan pailit, Rudy Setyopurnomo sudah melewati masa tersebut, dinyatakan pailit pada tahun 2003 dan baru diangkat kembali pada tahun 2012, dapat terhitung sudah 9 tahun dan melewati jangka waktu 5 tahun setelah dinyatakan pailit.

Kepailitan yang dialami oleh PT Indonesian Airlines Aviapatria juga bukan karena kesalahan oleh Rudy Setyopurnomo. Namun diakibatkan oleh pemegang saham yang lain untuk tidak ingin berinvestasi di bisnis penerbangan. Sesuai dengan Pasal 104 ayat 2 UUPT maka direksi tidak bertanggung jawab penuh akibat kepailitan yang terjadi tersebut. 


\section{Simpulan}

Perusahaan yang mengalami pailit maka yang dinyatakan dalam pengampuan adalah perusahaan tersebut. Direksi hanya sebagai organ perusahaan yang mewakili perusahaan tersebut. Di dalam direksi tersebut juga masih ada hak pribadi nya sebagai warga negara Indonesia. Menurut Undang-Undang Nomor 40 Tahun 2007 tentang Perseroan Terbatas dijelaskan bahwa tanggung jawab direksi hanya sebatas harta kekayaan. Jika terjadi pailit karena kesalahan dan kelalaian direksi maka direksi bertanggung renteng apabila harta kekayaan Perusahaan tidak cukup untuk menutupi utang pailit. Mengenai syarat pembatasan seorang direksi yang pailit untuk menjadi direksi di perusahaan lain terjadi konflik dengan pengaturan akibat kepailitan yang menyatakan seorang yang pailit hanya tidak berkuasa terhadap harta kekayaannya saja. Hal tersebut juga bertentangan dengan konsep dasar hak keperdataan.

1) Upaya hukum yang dapat dilakukan direksi yang pernah dinyatakan pailit untuk menjadi direksi di perusahaan lain adalah dengan melakukan gugatan perbuatan melawan hukum kepada notaris dan Kementerian Hukum dan HAM, karenanya jika ada notaris yang tidak bersedia membuat akta pengangkatan direksi tersebut maka telah merugikan hak keperdataan orang lain untuk mencari nafkah dan melanggar Kode Etik Notaris yang seharusnya membuatkan akta kepada para pihak yang menghadapnya. Sedangkan untuk Kementerian hukum dan HAM dapat digugat dengan perbuatan melawan hukum karena telah merugikan hak orang lain secara perdata dan dapat digugat juga di PTUN karena tidak sesuai dengan AAUPB karena telah menerbitkan undang-undang yang pada substansinya telah merugikan hak orang lain dan dengan tidak bertindak apapun yang dikatakan sebagai KTUN fiktif negatif telah menimbulkan kerugian kepada orang lain.

2) 


\section{Saran}

1) Untuk melindungi hak pribadi direksi sebagai subjek hukum maka perlu dipertimbangkan kembali mengenai isi UndangUndang 40 Tahun 2007 dan Undang-Undang 37 Tahun 2004 karena terjadi konflik dan ketidakselarasan mengenai tanggung jawab akibat kepailitan. Jikan memang direksi yang dinyatakan pailit tidak dapat menjadi direksi di perusahaan lain maka UU 37 Tahun 2004 juga harusnya mengatur lebih detail mengenai akibat pailit yang di tanggung oleh direksi.

2) Kementerian Hukum dan HAM juga perlu mengkaji ulang substansi dari undang-undang yang tidak selaras tersebut sesuai dengan AAUPB sehingga tidak dapat menimbulkan kerugian secara langsung maupun tidak langsung kepada masyarakat tidak hanya asal menerbitkan undang-undnag begitu saja.

\section{Daftar Pustaka}

\section{Buku}

Adjie, Habib, 2008, Sanksi Perdata dan Administratif terhadap Notaris sebagai Pejabat Publik, Bandung : Refika Aditama.

Ais, Chatamarrasjid, 2004, Penerobosan Cadar Perseroan dan Soal-Soal Aktual Hukum Perusahaan, Bandung : Citra Aditya Bakti.

Anshori, Abdul Ghofur,2010, Lembaga Kenotariatan Indonesia Perspektif Hukum dan Etika, Yogyakarta : UII Press.

Fuady, Munir, 2003, Perseroan Terbatas Paradigma Baru, Bandung : Citra Aditya Bakti.

\footnotetext{
- 2002, Hukum Perusahaan Dalam Paradigma Hukum Bisnis, Bandung : Citra Aditya Bakti.

, 2002, Doktrin-Doktrin Modern Dalam Corporate Law dan Eksistensinya Dalam Hukum Indonesia, Bandung : Citra Aditya Bakti.
}
- 2005, Perbuatan Melawan Hukum (Pendekatan Kontemporer), Bandung : Citra Aditya Bakti.
, 2005, Etika Profesi Hukum Bagi Hakim, Jaksa, Advokat, Notaris, Kurator, dan Pengurus, Bandung : Citra Aditya Bakti


Hadjon, Philipus M., R. Sri Soemantri Martosoewignjo, Sjachran Basah, Bagir Manan, H.M. Laica Marzuki, J.B.J.M. ten Berge, P.J.J. van Buuren, F.A.M. Stroink, 2008, Pengantar Hukum Administrasi Indonesia Introduction to the Indonesian Administrative Law, Yogyakarta : Gajah Mada University Press.

Hartono, Sri Redjeki, 2012, Hukum Kepailitan, Malang : UMM Press.

Hoff, Jerry,1999, Indonesian Bankruptcy Law, Jaarta : Tatanusa.

HR, Ridwan,2007, Hukum Administrasi Negara, Jakarta : PT Rajagrafindo Persada.

Marzuki, Peter Mahmud,2005, Penelitian Hukum, Jakarta : Kencana Prenada Media Group.

Prasetya, Rudhi, 2001, Kedudukan Mandiri Perseroan Terbatas Disertai dengan Ulasan Menurut UU Nomor 1 Tahun 1995 tentang Perseroan Terbatas, Citra Aditya Bakti, Bandung, 2001.

Prodjodikoro, Wirjono,2003, Asasasas Hukum Pidana Indonesia, Bandung : Refika Aditama.

Rido,R.Ali, 2001, Badan Hukum Perseroan, Perkumpulan, Kop erasi, Yayasan, Wakaf, Bandung : Alumni
Sjaifurrachman, 2011, Aspek Pertanggung-jawaban Notaris Dalam Pembuatan Akta, Bandung : Mandar Maju.

Subhan, M Hadi, 2012, Hukum Kepailitan (Prinsip, Norma, Dan Praktik Di Peradilan), Jakarta : Kencana Prenada Media Group.

Widiyono, Try, 2008, Direksi Perseroan Terbatas Keberadaan, Tugas, Wewenang, dan Tanggung Jawab, Bogor : Ghalia Indonesia.

Yani, Ahmad, dan Gunawan Widjaja, 2004, Kepailitan, Jakarta : PT. Raja Grafindo Persada.

Gatra Setya El Yanda, 2015, Pembatasan Hak Debitor Pailit Untuk Mnejadi Direksi Perseroan Terbatas, Artikel Ilmiah, Malang : Fakultas Hukum Universitas Brawijaya.

Wiwik Sriwiyati, 2003, Perbuatan Melawan Hukum Dalam Kasus Pemutusan Hubungan Kerja, Skripsi, Surabaya : Fakultas Hukum Universitas Airlangga.

Sjachran Basah,1989, Eksistensi dan Tolak Ukur Badan Peradilan Administrasi di Indonesia. Bandung : Alumni.

\section{Internet}

Rista Rama Dhany, "Siapakah Rudy Setyopurnomo, Sang Bos Baru Merpati ?", www.finance.detik.com, $\quad 16$ 
Mei 2012, dikunjungi pada tanggal 12 November 2012.

Angga Aditya, "Daftar Maskapai Penerbangan Indonesia yang Sudah 'Bangkrut',', www.finance.detik.com, $\quad 31$ Januari 2013, dikunjungi pada tanggal 12 November 2015.

\section{Undang-Undang}

Undang-Undang Dasar Negara Republik Indonesia Tahun 1945.

Kitab Undang-Undang Hukum Perdata yang diterjemahkan oleh Prof. R Subekti, S.H. dan R. Tjitrosudibio.

Undang-Undang Nomor 37 Tahun 2004 tentang Kepailitan dan Penundaan Kewajiban Pembayaran Utang.

Undang-Undang Nomor 40 Tahun 2007 tentang Perseroan Terbatas.

Undang-Undang Nomor 30 Tahun 2004 tentang Jabatan Notaris.

Undang-Undang Nomor 51 Tahun 2009 tentang Perubahan Kedua Undang-Undang Nomor 5 Tahun 1986 tentang Peradilan Tata Usaha Negara. 